\title{
In-vitro Efficacy of Sakura Block Plus Supplementation in Oil Palm Fronds (OPF) on Rumen Fermentation, Nutrient Digestibility, and Gas Production
}

\section{Jarmuji Jarmuji ${ }^{1,3}$, Lili Warly ${ }^{2 *}$, Mardiati Zain $^{2}$, Khasrad Khasrad ${ }^{2}$}

${ }^{1}$ Department of Animal Nutrition, Faculty of Animal Science Andalas University, Kampus Limau Manis, Padang, West Sumatera, Indonesia; ${ }^{2}$ Department of Animal Nutrition, Faculty of Animal Science Andalas University, Kampus Limau Manis, Padang, West Sumatera, Indonesia; ${ }^{3}$ Departemen of Animal science, University of Bengkulu, Bengkulu, 38371, Indonesia.

\begin{abstract}
This study aimed to obtain the level of sakura block plus as an in-vitro supplementary feed in Oil Palm Fronds (OPF) feed on optimizing rumen fermentation products, digestibility of nutrients, and gases production. Sakura block plus is a modification of commercial sakura block by using earthworm flour as a source of protein as a substitute for rice bran. The treatments were arranged as follow: $\mathrm{P} 0=\mathrm{OPF}+$ concentrate $+10 \%$ commercial sakura block, $\mathrm{P} 1=$ $\mathrm{OPF}+$ concentrate $+6 \%$ sakura block plus, $\mathrm{P} 2=\mathrm{OPF}+$ concentrate $+8 \%$ sakura block plus, $\mathrm{P} 3=\mathrm{OPF}+$ concentrate + $10 \%$ sakura block plus, $\mathrm{P} 4=\mathrm{OPF}+$ concentrate $+12 \%$ sakura block plus, $\mathrm{P} 5=\mathrm{OPF}+$ concentrate $+14 \%$ sakura block plus. Supplementation of sakura block plus in OPF was able to increase rumen fermentation products, digestibility of nutrients, and production of gases. The increase in the treatment of OPF supplemented with sakura block plus at a level of $12 \%$ was higher compared to the other treatments.
\end{abstract}

Keywords | Oil palm fronds, Sakura block plus, Rumen fermentation products, Digestibility of nutrients, Gases production

Received | December 09, 2021; Accepted | December 24, 2021; Published | January 15, 2022

*Correspondence | Lili Warly, Department of Animal Nutrition, Faculty of Animal Science Andalas University, Kampus Limau Manis, Padang, West Sumatera, Indonesia; Email: liliwarly_uapdg@yahoo.co.id

Citation | Jarmuji J, Warly L, Zain M, Khasrad K (2022). In-vitro efficacy of sakura block plus supplementation in oil palm fronds (OPF) on rumen fermentation, nutrient digestibility, and gas production. Adv. Anim. Vet. Sci. 10(3): 548-554.

DOI | http://dx.doi.org/10.17582/journal.aavs/2022/10.3.548.554

ISSN (Online) | 2307-8316

\section{INTRODUCTION}

$\mathrm{T}_{\mathrm{r}}$ The current growth of the palm oil industry which reaches 14.85 million ha is a leading commodity that contributes to the country's foreign exchange and the largest employment opportunities in Indonesia (Direktorat Jenderal Perkebunan, 2019). The palm oil industry in addition to producing oil also has the potential to produce quite large by-products that can be utilized as ruminant feed (Abubakr et al., 2015). By-products of oil palm plantations play an important role in the production of ruminants considering the decreasing availability of forage for livestock growing in oil palm plantation areas (Purwantari et al., 2015; Ooi et al., 2017). Palm fronds are by-products that are abundant and available throughout the year, which is $47 \%$ out of the total oil palm waste
(Nordin et al., 2017). Each hectare of oil palm plantations produces 6,500-7,500 fronds per year (Nurhaita et al., 2011; Hakim and Suherman, 2018; Pahan, 2021). Oil Palm Fronds (OPF) cannot be given to ruminants in a single form because they have a very high fiber content (Ebrahimi et al., 2015; Warly et al., 2015; Rusli et al., 2021), and lignin up to 30\% (Febrina et al., 2016), as well tannins and phenolics (Jaffri et al. 2011) which can inhibit rumen microbial synthesis (Pollegioni et al., 2015; Li et al., 2016; Febrina et al., 2018; Wang et al., 2020). Therefore, the use of palm fronds as animal feed must be made to establish pretreatment methods of OPF to improve the nutritional quality and rumen microbial synthesis (Warly et al., 2017; Chanjula et al., 2017; Nunes and Kumar, 2018; Rusli et al., 2019). 
Sakura block is a feed supplement modified by urea molasses block (UMB) with a mixed formulation of the main raw materials of waste coconut sugar, bran, corn, sago, urea, and minerals that can provide a balance of energy, nitrogen, and other soluble nutrients needed for rumen microbial growth. as the main source of protein for the growth and production of beef cattle (Jarmuji et al., 2017; Santoso et al., 2017), dairy cattle (Jarmuji et al., 2021a), and dairy goat (Soetrisno et al., 2018). Sakura block plus is a modification of commercial sakura block by using $6 \%$ earthworm flour as a substitute for rice bran and palm kernel cake as a substitute for corn. Sakura block plus contains $25.28 \%$ crude protein, $4.62 \%$ crude fiber dan 87.76 Total Digestible Nutrient. Sakura block plus as a dietary supplement is very good for increasing rumen fermentation products and digestibility (Jarmuji et al., 2021b). Efforts to enrich the nutrition of sakura block by utilizing earthworms as a protein source need to be carried out to support the development of an integrated system for oil palm cattle in Indonesia. Earthworms are decomposers of organic matter in providing nutrients (Jarmuji et al., 2016; Dani et al., 2017; Hazra et al., 2018) and contain gibelerin and auxin (Ferreras et al., 2006) required for the growth of oil palm.

The utilization of OPF as an animal feed substitute for forage is very important to be applied to support the integration system of oil palm cattle in Indonesia. This study aimed to obtain the appropriate in-vitro level of sakura block plus $(6,8,10,12$, and $14 \%)$ in palm fronds as animal feed that will contribute to the good enhancement of rumen fermentation products and digestibility.

\section{MATERIALS AND METHODS}

\section{ETHICAL APPROVAL}

This study did not include the use of any live animals so, ethical approval is not required to be issued and submitted.

\section{SAMPLING}

The composition of the raw materials sakura block plus is presented in Table 1. Sakura block plus was handled as follows: the ingredients in the form of flour were mixed homogeneously, while water-soluble ingredients such as rejected brown sugar, urea, and salt were dissolved in water as much as $7 \%$ of the total ingredients, then heated over low heat until dissolved. The dry ingredients were mixed with liquid ingredients until evenly distributed and printed. Sakura blocks plus that have been printed were dried for 2-3 days. Palm fronds were obtained by harvesting oil palms, removing $1 / 3$ of the hard-base and outer skin, then the palm fronds were chopped up to a size of $1-2 \mathrm{~cm}$ and air-dried until the moisture content achieved 40\%. Urea was suscitated up to $3 \%$ of the total dry ingredients of the palm fronds and stirred until evenly distributed, put in a plastic bag while compacting and tied to make it airtight. After 21 days the plastic bag was opened, aired for 2 hours before being used as a feed. Cassava flour was made from rejected cassava which is peeled off the outer skin, dried in the sun, and ground into flour. Rejected cassava was categorized as a substance that did not meet the requirements for processing because its size was too small (diameter $1-3 \mathrm{~cm}$ ). Palm oil cake was obtained from the by-product of palm kernel oil processing which was widely distributed in Indonesia.

Table 1: Ingredient and nutrient sakura block commercial and sakura block plus.

\begin{tabular}{|lll|}
\hline Ingredient (\%) & $\begin{array}{l}\text { Sakura block } \\
\text { commercial }\end{array}$ & $\begin{array}{l}\text { Sakura block plus } \\
\text { earthworm }\end{array}$ \\
\hline Rejected brown sugar & 32.0 & 32.0 \\
\hline Rice barn & 28.0 & 22.0 \\
\hline Corn & 15.0 & 0.0 \\
\hline Palm kernel cake & 0.0 & 15.0 \\
\hline Earthworm flour & 0.0 & 6.0 \\
\hline Sagoo & 15.0 & 15.0 \\
\hline Urea & 5.0 & 5.0 \\
\hline Salt & 2.0 & 2.0 \\
\hline Triple superphospate & 1.0 & 1.0 \\
\hline Mineral mix & 1.0 & 1.0 \\
\hline Topmix & 1.0 & 1.0 \\
\hline Total & 100 & 100 \\
\hline Nutrient (\% dry matter) & & \\
\hline Organic matter & 93.55 & 93.85 \\
\hline Crude protein & 17.83 & 25.28 \\
\hline Crude fiber & 3.67 & 4.62 \\
\hline extract ether & 3.00 & 3.05 \\
\hline Nitrogen free extract & 54.11 & 51.55 \\
\hline TDN & 78.87 & 87.10 \\
\hline Source: Ruminant Animal Nutrition & Laboratory, Faculty of \\
Animal Husbandry, Andalas University (2021).
\end{tabular}

\section{EXPERIMENTAL DESIGN}

The study used a completely randomized design with 6 treatments and 3 replicates consisting of: $\mathrm{P} 0=\mathrm{OPF}+$ concentrate $+10 \%$ commercial sakura block, $\mathrm{P} 1=\mathrm{OPF}+$ concentrate $+6 \%$ sakura block plus, $\mathrm{P} 2=\mathrm{OPF}+$ concentrate $+8 \%$ sakura block plus, $\mathrm{P} 3=\mathrm{OPF}+$ concentrate $+10 \%$ sakura block plus, $\mathrm{P} 4=\mathrm{OPF}+$ concentrate $+12 \%$ sakura block plus, and $\mathrm{P} 5=\mathrm{OPF}+$ concentrate $+14 \%$ sakura block plus. The ingredients and nutritional composition of the palm fronds feed were presented in Table 2.

\section{Chemical analyzes}

Each sample was analyzed to determine the dry matter, 
organic matter, crude protein, crude fiber, extract ether, and ash using proximate analysis (AOAC, 2005). Neutral Detergent Fiber (NDF), Acid Detergent Fiber (ADF), cellulose, hemicellulose contents were analyzed using Van Soest analysis (Goering and Van Soest, 1970).

Table 2: Ingredient and nutrient of ransom (\% of dry matter).

\begin{tabular}{|c|c|c|c|c|c|c|}
\hline \multirow{2}{*}{$\begin{array}{l}\text { Ingredient (\% dry } \\
\text { matter) }\end{array}$} & \multicolumn{6}{|c|}{ Treatment } \\
\hline & P0 & P1 & P2 & P3 & P4 & P5 \\
\hline OPF & 40 & 40 & 40 & 40 & 40 & 40 \\
\hline Cassava & 25 & 25 & 25 & 25 & 25 & 25 \\
\hline Dregs tofu & 10 & 14 & 12 & 10 & 8 & 6 \\
\hline Palm kernel cake & 15 & 15 & 15 & 15 & 15 & 15 \\
\hline $\begin{array}{l}\text { Sakura block } \\
\text { commercial }\end{array}$ & 10 & 0 & 0 & 0 & 0 & 0 \\
\hline Sakura block plus & 0 & 6 & 8 & 10 & 12 & 14 \\
\hline Total & 100 & 100 & 100 & 100 & 100 & 100 \\
\hline \multicolumn{7}{|l|}{ Nutrient (\%) } \\
\hline Organic matter & 86.49 & 86.7 & 86.62 & 86.54 & 86.46 & 86.38 \\
\hline Crude protein & 13.1 & 13.48 & 13.53 & 13.58 & 13.63 & 13.68 \\
\hline Extract ether & 4.26 & 4.4 & 4.33 & 4.26 & 4.19 & 4.12 \\
\hline Ash & 3.51 & 3.3 & 3.38 & 3.46 & 3.54 & 3.62 \\
\hline Nitrogen free extract & 46.21 & 45.32 & 45.63 & 45.95 & 46.26 & 46.58 \\
\hline $\begin{array}{l}\text { Total digestible } \\
\text { nutrient }\end{array}$ & 65.28 & 65.75 & 65.72 & 65.7 & 65.67 & 65.64 \\
\hline
\end{tabular}

\section{IN-VITRO TRIAL ON THE INFLUENCE OF SAKURA BLOCK} PLUS

In-vitro analysis was carried out to determine the $\mathrm{pH}$, ammonia, total volatile fatty acid, acetic, propionic, and butyric of each feed component using the Tilley and Terry method (Tilley and Terry, 1969), performed for $48 \mathrm{~h}$ for forage and $24 \mathrm{~h}$ for concentrate. Incubation was stopped by immersing the Erlenmeyer flask into ice water to stop the microbial activity, after which $\mathrm{pH}$ measurement was carried out using a $\mathrm{pH}$ meter. Next, the supernatant was separated from the residue. To do this, the mixture obtained from the in-vitro analysis was put into a centrifuge tube and then centrifuged for $30 \mathrm{~min}, 3000 \mathrm{rpm}$, at $4^{\circ} \mathrm{C}$. The supernatant was stored in bottles and then frozen until subsequent analysis was carried out.

The concentration of ammonia was determined using the Conway method, total volatile fatty acid concentration was determined using steam distillation. acetic, propionic and butyric concentrations were determined using gas chromatography. The residues were filtered using a Whatman No. 41 filter paper and then dried in an drying oven model DHG-9053A at $60^{\circ} \mathrm{C}$. Afterward, it was analyzed for nutrient digestibility using the proximate analysis method, and fiber fraction digestibility using the Van Soest analysis method (Goering and Van Soest, 1970). The procedure for measuring gas production was carried out by modifying the pressure transducer tool. Measurement of gas production was carried out during the incubation period of in-vitro feed samples for 24 and 48 hours.

\section{STATistical ANALYSis}

All data were subjected to analyses of variance of completely randomized design using using SPSS software version 25.0 (SPSS, 2017). IBM SPSS Statistics for Windows, Version 21.0. Armonk, NY: IBM Corp. The results were presented as the mean values and standard error of the means. Differences between treatment means were tested by Duncan's multiple range test method and declared significant at $\mathrm{P}<0.05$ (Harsojuwono et al., 2021).

\section{RESULTS AND DISCUSSION}

\section{The EfFect of SAKURA BLOck plus on RUMEN FERMENTED PRODUCTS}

Fermentability of feed by rumen microbial is the effort of microorganisms to obtain energy, carbon and nitrogen for their reproduction (Hapsari et al., 2018). The concentration of ammonia $\left(\mathrm{NH}_{3}\right)$, total Volatile fatty acid (VFA), acetic, and propionic acids as revealed in Table 3 increased significantly $(\mathrm{P}<0.05)$ in the treatment of OPF supplemented with sakura block plus. However, the concentration of $\mathrm{pH}$ and butyrate did not show a significant difference. The concentration of rumen fluid $\mathrm{pH}$ in this study ranged from 6.70 to 6.9 , these result are similar to rumen microbial growth (Ismartoyo, 2011; Jamarun et al., 2019). Rumen $\mathrm{pH}$ is the major factors affecting rumen microbial produces fermented products in the form of volatile fatty acid and ammonia (Huyen et al., 2016).

The highest increase in ammonia concentration was found in the sakura block plus treatment $12 \%(\mathrm{P} 4)$ of up to $10.66 \mathrm{mM}$ or an increase of $28.74 \%$ from the ammonia concentration in the commercial sakura block treatment (P0), while the ammonia concentration in sakura block plus the level 14\% (P5) was lower than P4 as much as $9.66 \mathrm{nM}$. As with ammonia, the highest rumen total volatile fatty acid concentration was produced in the $12 \%$ treatment (P4). The total VFA concentration of P4 treatment was $108.28 \mathrm{nM}$ or an increase of $10.87 \%$ from the commercial sakura block treatment (P0). The concentration of total VFA in the 14\% (P5) treatment was lower than that of P4.

Acetate, propionate, and butyrate were the main components of VFA, while other components were recorded in very small amounts such as isobutyrate, valerate, isovalerate (Czerkawski, 1986). The concentration 
of acetate and propionate increased significantly in the OPF supplemented with sakura block plus compared to commercial sakura block treatment $(\mathrm{P} 0)$.

The increase in rumen fermentation products (ammonia, total volatile fatty acid, acetate, and propionate) in OPF supplemented with sakura block plus was due to the high content of branched amino acids (valine, leucine, and isoleucine) in earthworms (Hayati et al., 2011) and it has a role in increasing the synthesis and growth of rumen microbes (Li et al., 2005; Zain et al., 2008; Zhang et al., 2013). Valine, leucine, and isoleucine undergo decarboxylation and deamination to produce Branched Chain Volatile Fatty Acid (BCVFA) (Andries et al., 1987). $\mathrm{BCVFA}$ is used as a carbon skeleton donor in the formation of amino acids during the protein synthesis process (Russel and Sniffen, 1984). Several groups of cellulolytic bacteria such as Fibrobacter succinogenes, Ruminoccocus albus, R. flavefacius, and amylolytic bacteria such as Prevotella ruminicola, Butyrivibrio fibrosolvens, Selenomonas ruminantium, and Succinimonas amylolytica, Ruminococcus albus, and Enterostridium cloacae that require protein and are degraded from carbohydrates and high fiber such as palm fronds (Baldwin and Allison, 1983). Tylutki and Fox (1997) revealed that leucine deficiency in fibrous diets caused a decrease in the growth rate of rumen microbes. The results of this study are in line with the results of previous studies. The addition of worm flour as a source of branched amino acids (BCAA) above the normal limit in the diet can reduce ammonia, volatile fatty acid, and inhibit rumen microbial synthesis, this is might be attributed to that leucine and isoleucine are more difficult to synthesize rumen microbes (Atasoglu et al., 2004). Earthworm meal supplementation of $6 \%$ in commercial sakura blocks was significantly more optimal in increasing concentrations of ammonia and Volatile fatty acid compared to worm flour supplementation above 6\% (Jarmuji et al., 2021b). Sihombing et al. (2010) stated that increasing the level of earthworm flour to a level of $6 \%$ in the ration did not significantly improve performance in livestock. The normal limit for the addition of valine, leucine, and isoleucine in the diet of ruminants is $2 \mathrm{mmol} / \mathrm{L}$ (Zhang et al., 2013).

\section{The EFFECT OF SAKURA BLOCK PLUS ON NUTRIENT DIGESTIBILITY}

Assessment of the quality of animal feed ingredients is not enough to determine the value of the food substances contained therein, but the value of these ingredients for livestock can be determined after undergoing digestion, absorption, and metabolism in the rumen and post-rumen organs (Chruch and Pond, 1988). The results displayed in Table 4 showed a significant increase $(\mathrm{P}<0.05)$ in nutrient digestibility in palm frond supplemented with sakura block plus earthworms, except for the Acid Detergent
Fiber (ADF) component.

The increase of the level of sakura block plus to a level of $12 \%$ in palm frond (P4) produced the most optimal nutritional digestibility value compared to others. The increase of sakura block plus supplementation up to the level of 14\% (P5) although produced an increase in digestibility value, it was not significantly different from $\mathrm{P} 4$. The high value of $\mathrm{P} 4$ nutrient digestibility was due to the ability of microorganisms to degrade and digest feed ingredients that enter the rumen. The digestive process in the rumen was very dependent on the population and types of microbes that develop in the rumen because the process of reforming feed is the responsibility of the rumen microbes (Arora, 1995; Puastuti, 2009). The increase in the rumen microbial population implied an increase in the production of enzymes in the rumen so that it is expected to increase feed digestibility, as well as increase the supply of microbial protein for the landlady. Rumen microbial population can be increased through the nutrient adequacy approach for its growth (Zain et al., 2008). The Sakura block plus earthworm treatment at $12 \%$ level (P4) was thought to have the right balance between the availability of protein and carbohydrates in the ration for rumen microbial synthesis compared to the commercial sakura block treatment $(\mathrm{P} 0)$ and other treatments $(\mathrm{P} 1, \mathrm{P} 2, \mathrm{P} 3$, and $\mathrm{P} 5)$. Energy and carbon atoms (C) were produced from the degradation of carbohydrates and the main amino groups were obtained from $\mathrm{NH}_{3}$ as a result of protein degradation and non-protein nitrogen (NPN) in feed ingredients (Russel et al., 1992; Ginting, 2015).

\section{The EfFect of SAKURA BLOCK Plus ON THE}

\section{PRODUCTION OF GAS}

Observation showed (Table 5) that the cumulative gas production between treatments during the incubation period of 24 and 48 hours and was significantly different between treatments $(\mathrm{P}<0.05)$.

As is the case with 24-hour incubation, cumulative gas production for 48 hours on the cherry-block plus treatment also saw a noticeable increase. The highest increase was in the P4 treatment of 101.33 or an increase of $49.25 \%$ from $\mathrm{P} 0$. Gases production is an indicator of the process of fermentation of feed by rumen microbes, gas production can be a benchmark of the process of degradation of feed by microbes that produce substrate for fermentation. Furthermore, a high rumen microbial population can increase the fermentation process of feed substrates to produce volatile fatty acids to meet carbon needs and as the main energy source for rumen microbes, biomass, and some gases like $\mathrm{CH}_{4}$ and $\mathrm{CO}_{2}$ (Liu et al., 2002; Trotta et al., 2018). 
Table 3: The Effect of different concentrations of sakura block plus on the ruminal fermentation products.

\begin{tabular}{lllllll} 
Parameter & \multicolumn{5}{c}{ Treatment } \\
& P0 & P1 & P2 & P3 & P4 & P5 \\
$\mathrm{Ph}$ & $6.70 \pm 0.78$ & $6.70 \pm 0.57$ & $6.80 \pm 0.83$ & $6.90 \pm 0.23$ & $6.90 \pm 0.33$ & $6.85 \pm 0.42$ \\
$\mathrm{NH}_{3}(\mathrm{mM})$ & $8.28 \pm 1.11^{\mathrm{a}}$ & $8.85 \pm 0.64^{\mathrm{ab}}$ & $9.17 \pm 0.19^{\mathrm{abc}}$ & $9.95 \pm 0.40^{\mathrm{bc}}$ & $10.66 \pm 1.05^{\mathrm{c}}$ & $9.66 \pm 1.06^{\mathrm{abc}}$ \\
\hline Total VFA $(\mathrm{mM})$ & $97.66 \pm 4.66^{\mathrm{a}}$ & $99.63 \pm 4.61^{\mathrm{ab}}$ & $105.45 \pm 3.19^{\mathrm{bc}}$ & $107.13 \pm 2.95^{\mathrm{c}}$ & $108.28 \pm 2.62^{\mathrm{c}}$ & $105.94 \pm 3.83^{\mathrm{bc}}$ \\
\hline Acetic $(\mathrm{mM})$ & $47.40 \pm 3.21^{\mathrm{a}}$ & $50.55 \pm 2.21^{\mathrm{ab}}$ & $52.69 \pm 2.17^{\mathrm{b}}$ & $52.94 \pm 0.61^{\mathrm{b}}$ & $53.15 \pm 1.16^{\mathrm{b}}$ & $51.36 \pm 1.67^{\mathrm{b}}$ \\
Propionic $(\mathrm{mM})$ & $25.00 \pm 1.13^{\mathrm{a}}$ & $24.75 \pm 1.63^{\mathrm{a}}$ & $26.87 \pm 0.61^{\mathrm{ab}}$ & $27.33 \pm 0.94^{\mathrm{b}}$ & $28.46 \pm 1.39^{\mathrm{b}}$ & $27.38 \pm 1.68^{\mathrm{b}}$ \\
Butyric $(\mathrm{mM})$ & $9.52 \pm 0.21$ & $9.32 \pm 0.71$ & $9.78 \pm 0.83$ & $10.38 \pm 0.62$ & $10.42 \pm 0.73$ & $10.07 \pm 0.37$
\end{tabular}

Mean \pm Standard Deviation. Source: livestock research center laboratory, Ciawi. Bogor (2021).

Table 4: Effect of different concentrations of sakura block plus on the Digestibility nutrient.

\begin{tabular}{lllllll} 
Parameter & \multicolumn{5}{c}{ Treatment } \\
& P0 & P1 & P2 & P3 & P4 & P5 \\
Dry matter digestibility & $59.74 \pm 3.69^{\mathrm{a}}$ & $59.72 \pm 4.22^{\mathrm{a}}$ & $62.76 \pm 2.07^{\mathrm{ab}}$ & $65.94 \pm 1.84^{\mathrm{b}}$ & $67.13 \pm 1.18^{\mathrm{b}}$ & $66.76 \pm 1.67^{\mathrm{b}}$ \\
Organic matter digestibility & $63.35 \pm 1.85^{\mathrm{a}}$ & $63.58 \pm 2.10^{\mathrm{a}}$ & $67.17 \pm 2.13^{\mathrm{b}}$ & $66.96 \pm 1.12^{\mathrm{b}}$ & $67.78 \pm 1.59^{\mathrm{b}}$ & $67.94 \pm 1.41^{\mathrm{b}}$ \\
Crude Protein digestibility & $34.10 \pm 2.99^{\mathrm{a}}$ & $35.86 \pm 1.48^{\mathrm{a}}$ & $36.88 \pm 3.46^{\mathrm{ab}}$ & $41.77 \pm 2.85^{\mathrm{bc}}$ & $43.41 \pm 3.35^{\mathrm{c}}$ & $45.70 \pm 1.99^{\mathrm{c}}$ \\
ADF digestibility & $67.38 \pm 0.85$ & $68.84 \pm 2.47$ & $70.65 \pm 3.05$ & $69.27 \pm 0.53$ & $68.62 \pm 1.60$ & $69.21 \pm 4.09$ \\
NDF Digestibility & $39.75 \pm 0.51^{\mathrm{a}}$ & $41.57 \pm 2.36^{\mathrm{ab}}$ & $44.14 \pm 2.89^{\mathrm{bc}}$ & $42.03 \pm 0.60^{\mathrm{ab}}$ & $45.51 \pm 1.27^{\mathrm{c}}$ & $43.85 \pm 1.25^{\mathrm{bc}}$
\end{tabular}

Mean \pm Standard Deviation. Source: nutrition laboratory, livestock research center, Ciawi. Bogor (2021).

Table 5: Effect of different concentrations of sakura block plus on the production of methane gas for 24 and 48 hours.

\begin{tabular}{lllllll} 
Parameter & \multicolumn{5}{c}{ Treatment } \\
& P0 & P1 & P2 & P3 & P4 & P5 \\
Production of gases (24 hours) & $58.67 \pm 1.52^{\mathrm{a}}$ & $70.33 \pm 0.57^{\mathrm{b}}$ & $71.02 \pm 1.03^{\mathrm{b}}$ & $82.67 \pm 0.58^{\mathrm{c}}$ & $83.00 \pm 0.06^{\mathrm{c}}$ & $83.00 \pm 1.02^{\mathrm{c}}$ \\
Production of gases (48 hours) & $67.67 \pm 1.53^{\mathrm{a}}$ & $82.33 \pm 0.5^{\mathrm{b}}$ & $89.00 \pm 1.07^{\mathrm{c}}$ & $95.67 \pm 0.58^{\mathrm{d}}$ & $101.33 \pm 1.15^{\mathrm{e}}$ & $101.00 \pm 1.07^{\mathrm{e}}$ \\
Mean \pm Standard Deviation. Source: nutrition laboratory, livestock research center, Ciawi. Bogor (2021).
\end{tabular}

The results of this study showed that sakura block plus as supplement feed enriched with earthworm flour has a positive impact on increasing the degradation and digestibility value of high-fiber palm oil feed. Earthworms as a source of protein and sources of branched amino acids are excellent for increasing the growth of rumen microbes which have a major role in degrading fibrous feed to produce volatile fatty acids, biomass, and gases ( $\mathrm{Li}$ et al., 2005; Zain et al., 2008; Zhang et al., 2013). Wang et al. (2008) stated that feed derived from agricultural and plantation waste such as palm oil palms generally contains very low-branched amino acids so that it can reduce the growth rate of rumen microbes.

\section{CONCLUSIONS AND RECOMMENDATIONS}

Supplementation of sakura block plus $12 \%$ in palm frond significantly increased rumen fermentation products (ammonia, total volatile fatty acid, acetate, and propionate), and nutrient digestibility (dry matter, organic matter, crude protein, and neutral detergent fiber).

\section{ACKNOWLEDGEMENTS}

The authors are grateful to the Directorate General of Higher Education, The Ministry of Education and Culture for funding this research under the scheme of Doctoral Research of Dissertation (Penelitian Disertasi Doktor) with contract number: 104/E4.1/AK.04.PT/2021. This research was carried out well with technical assistance from the staff of the Ruminant Animal Nutrition Laboratory, Faculty of Animal Husbandry, Andalas University

\section{AUTHOR'S CONTRIBUTION}

JJ, LW, MZ, and KK formulated experimental designs and experimental work in the laboratory. JJ compiled the manuscript and performed data analysis under the supervision of LW, MZ, and KK. All authors read and agreed to the final version of the manuscript.

\section{CONFLICT OF INTEREST}

The authors have declared no conflict of interest. 


\section{REFERENCES}

Abubakr A, Alimon AR, Yaakub H, Abdullah N, Ivan M (2015). Effect of feeding palm oil by-products based diets on muscle fatty acid composition in goats. PLoS One, 10(3): e0119756. https://doi.org/10.1371/journal.pone.0119756

Andries, JL, Buysse, FX, De Brabander, DL, Cottyn, BG (1987). Isoacids in ruminant nutrition: Their role in ruminal and intermediary metabolism and possible influenced on performance. A review. Anim. Feed Sci. Technol., 18: 169180. https://doi.org/10.1016/0377-8401(87)90069-1

AOAC (2005). Official methods of analysis. $18^{\text {th }}$ ed. Association of official analytical, chemists international, Maryland, USA.

Arora SP (1995). Pencernan mikrobia pada ruminansia. Gajah mada University Press, Yogyakarta.

Atasoglu C, Guliye AY, Wallace RJ (2004). Use of stable isotopes to measure de novo synthesis and turnover of amino acid-C and $-\mathrm{N}$ in mixed microorganisms from the sheep rumen in vitro. J. Nutr., 91: 235-261. https://doi.org/10.1079/ BJN20031040

Baldwin RL, Allison MJ (1983). Rumen metabolism. J. Anim. Sci., 57: 2209-2215.

Chanjula P, Petcharat V, Cherdthong A (2017). Effects of fungal (Lentinussajor-caju) treated oil palm frond on performance and carcass characteristics in finishing goats. Asian Austral.J. Anim. Sci., 30(6): 811. https://doi.org/10.5713/ajas.16.0704

Church DC, Ponds WG (1988). Basic animal nutrition and feeding. $2^{\text {nd }}$ Ed. Jhon Wiley and Sons. New York. https://doi. org/10.1016/B978-0-08-025486-9.50007-4

Czerkawski JW (1986). An introduction to rumen studies. $1^{\text {st }}$ ed. Pergamon Press, New York.

Dani IR, Jarmuji, Pratama AW, Nugraha DA (2017). Collaboration of mesaba (cow and sheep feces media) to the response of earthworms (Pheretima sp.). J. Sain Peternak. Indonesia, 12(3): 308-316. https://doi.org/10.31186/jspi. id.12.3.308-316

Direktorat Jenderal Perkebunan (2019). Statistik Perkebunan Indonesia 2018-2020, Kelapa Sawit. Direktorat Jenderal Perkebunan Kementrian Pertanian

Ebrahimi M, Rajion MA, Goh YM, Shokryzadan P, Sazili AQ (2015). Feeding oil palm (Elaeis guineensis Jacg) fronds alters rumen protozoal population and ruminant fermentation pattern in goat. Ital. J. Anim. Sci., 14: 3877. https://doi. org/10.4081/ijas.2015.3877

Febrina D, Febriyanti R, Zam SI, Handoko J, Fatah A, Juliantoni J (2018). Anti bacterial activity testing and ethanol extract characterization of oil palm fronds (Elaeis guineensis Jacq). Pak. J. Nutr., 17(9): 427-433. https://doi.org/10.3923/ pjn.2018.427.433

Febrina D, Jamarun N, Zain M, Khasrad (2016). The effects of P, $\mathrm{S}$ and $\mathrm{Mg}$ supplementation of oil palm fronds fermented by Phanerochaete chrysosporium on rumen fluid characteristics and microbial protein synthesis. Pak. J. Nutr., 15: 299-304. https://doi.org/10.3923/pjn.2016.299.304

Ferreras L, Gomez E, Toresani E, Firpo I, Rotondo R (2006). Effect of organic amendments on some physical, chemical and biological properties in a horticultural soil. Biores. Technol., 97: 635-640. https://doi.org/10.1016/j. biortech.2005.03.018

Ginting SP (2015). Synchronization of protein and energy degradation in the rumen to maximize microbial protein production. Wartazoa, 15(1): 1-10.

Goering HK, Van Soest PJ (1970). Forage fiber analyses.
(Apparatus, reagents, procedures, and some applications). Agriculture Handbook No. 379. United States Department of Agriculture, Washington, DC. pp. 1-20.

Hakim M, Suherman C (2018). Replanting Kelapa Sawit. Penebar Swadaya Jakarta

Hapsari NS, Harjanti DW, Muktiani A (2018). Fermentabilitas Pakan dengan Imbuhan Ekstrak Daun Babadotan (Ageratum conyzoides) dan Jahe (Zingiber officinale) pada Sapi Perah secara in vitro. Agripet, 18(1): 1-9. https://doi. org/10.17969/agripet.v18i1.9672

Harsojuwono BA, Arnata IW, Diah Puspawati GAK, Kartika Pratiwi IDP (2021). Rancangan percobaan teori dan aplikasi. Edisi 1. Inteligensia Media, Malang

Hayati SN, Herdian H, Damayanti E, Istiqomah L, Julendra H (2011). The amino acid profile of the earthworm (Lumbricus rubellus) extract started with the spray drying method. Indones. J. Technol., 34, Special Edition.

Hazra F, Dianisa N, Widyastuti R (2018). Quality and production of vermicompost using african night crawler worms (Eudrilus eugeniae). J. Il. Tan. Lingk, 20(2): 77-81. https://doi.org/10.29244/jitl.20.2.77-81

Huyen NT, Fryganas C, Uittenbogaard G, Mueller-Harvey I (2016). Structural features of condensed tannins affect in vitro ruminal methane production and fermentation characteristics. J. Agric. Sci., 154(8): 1474-1487. https://doi. org/10.1017/S0021859616000393

Ismartoyo (2011). Degradasi pakan ruminansia. Publisher. Brilliant International. Surabaya.

Jaffri, JM, Mohamed S, Ahmad IN, Mustapha NM, Manap YA, Rohimi N (2011). Effects of catechin-rich oil palm leaf extract on normal and hypertensive rats' kidney and liver. Food Chem., 128: 433-441. https://doi.org/10.1016/j. foodchem.2011.03.050

Jamarun N, Pazla R, Zain M, Arief (2019). Comparison of in vitro digestibility and rumen fluid characteristics between the tithonia (Tithonia diversifolia) with elephant grass (Pennisetum purpureum). IOP Conf. Series: Earth Environ. Sci., 287: 012019. https://doi.org/10.1088/17551315/287/1/012019

Jarmuji, Santoso U, Brata B (2017). Effect of oil palm fronds and Setaria sp. as forages plus sakura block on the performance and nutrient digestibility of kaur catle. Pak. J. Nutr., (Vol and Pages?). Open acces. ISSN 1680-5194.

Jarmuji, Santoso U, Brata B and Cibro (2016). Effect of media of kaur cow feces utilizing palm fronds on klitelium development and children earthworm (Pheretima sp) production. Prosiding. International Seminar sustainable utilization of coastal resources in tropical zone, 19-20 October, 2016. Bengkulu, Indonesia. University of Bengkulu. pp. 413-418.

Jarmuji, Suherman D, Yanuri, Afriansyah R, Sulistyowati E (2021a). Effect of sakura block on milk production and milk quality of FH cows in late lactation. J. Sain Peternak. Indonesia, 16(3): 266-272. https://doi.org/10.31186/jspi. id.16.3.266-272

Jarmuji, Warly L, Zain M, Khasrad (2021b). Improving sakura block quality as feed supplement to optimize rumen fermentation products and nutrients digestibility in vitro. Adv. Anim.Vet. Sci., 9(10): 1594. https://doi.org/10.17582/ journal.aavs/2021/9.10.1594.1600

Li Y, Sun Z, Ge X, Zhang J (2016). Effects of lignin and surfactant on adsorption and hydrolysis of cellulases on cellulose. Biotechnol. Biofuels., 9(1): 20. https://doi.org/10.1186/ 
s13068-016-0434-0

Li, JY, Suzuki K, Koike Y, Chen DS, Yonezawa T, Nishihara IM, Manabe N (2005). Effects of dietary supplementation with Branched-chain Amino Acids (BCAA) during nursing on plasma BCAA Levels and subsequent growth in cattle. Asian Aust. J. Anim. Sci., 18(10): 1440-1444. https://doi. org/10.5713/ajas.2005.1440

Liu JX, Susenbeth S, Sudekum KH (2002). In vitro gas production measurements to evaluate interaction betwen untreated and chemically treated rice straws, grass bay and mulberry leaves. J. Anim. Sci., 80: 517-514. https://doi. org/10.2527/2002.802517x

Nordin NA, Sulaiman O, Hashim R, Kassim MHM (2017). Oil Palm frond waste for the production of cellulose nanocrystals. J. Phys. Ther. Sci., 28(2): 115-126. https://doi. org/10.21315/jps2017.28.2.8

Nunes CS, Kumar V (2018). Enzymes in human and animal nutrition: principles and perspectives. Academic Press, Cambridge, USA. pp. 107-123. https://doi.org/10.1016/ B978-0-12-805419-2.00006-X

Nurhaita, Ruswendi R, Wismalinda, Robiyanto (2011). Pemanfaatan pelepah sawit sebagai sumber hijauan dalam ransum sapi potong. Pastura, 4(1): 38-41.

Ooi ZX, Teoh YP, Kunasundari B, Shuit SH (2017). Oil palm frond as a sustainable and promising biomass source in Malaysia: A review. Environ. Prog. Sustain. Energy (in press). https://doi.org/10.1002/ep.12642

Pahan I (2021). Panduan Budidaya Kelapa Sawit untuk Pekebun. Penebar Swadaya, Jakarta

Pollegioni L, Tonin F, Rosini E (2015). Lignin-degrading enzymes. FEBS J., 282(7): 1190-1213. https://doi. org/10.1111/febs.13224

Puastuti W (2009). Manipulation of bioprocesses in the rumen to increase use of fibrous feed. Wartazoa, 19(04): 180-190.

Purwantari ND, Tiesnamurti D, Adinata Y (2015). Ketersediaan sumber hijauan dibawah perkebunan kelapa sawit untuk pengembalaan sapi. Wartazoa, 25(1): 47-54.

Rusli ND, Abdul Gani AA, Mat K. Yusof MT, Zambi-Saad M, Hassim HA (2021). The potential of petreated oil pal frond in enhancing rumen degrability and growth performance: A review. Adv. Anim. Vet. Sci., 9(6): 811-822. https://doi. org/10.17582/journal.aavs/2021/9.6.811.822

Rusli ND, Azmi MA, Mat K, Hasnita CH, Wan-Zahari M, Azhar K, Zamri-Saad M, Hassim HA (2019). The effect of physical and biological pre-treatments of oil palm fronds on in vitro ruminal degradability. Pertanika J. Trop. Agric. Sci., 42(2): 791-805.

RusselJB, Connor JDO, Fox DG, Van Soest PJ, Sniffen CJ (1992). A net carbohydrate and protein system for evaluating cattle diets: I. Ruminal fermentation. J. Anim. Sci., 70: 3551-3561. https://doi.org/10.2527/1992.70113551x

Russel JB, Sniffen CJ (1984). Effect of carbon 4 and carbon 5 volatile fatty acid on growth of mix rumen bacteria in vitro. J. Dairy Sci., 67: 987-995. https://doi.org/10.3168/jds. S0022-0302(84)81397-1

Santoso U, Jarmuji, Brata B (2017). Increasing farmer income through cow-palm earthworm integration technology. Case study in Wonoharjo Village, Girimulya District, North
Bengkulu Regency. J. Sain Peternak. Indonesia, 12(3): 3440. https://doi.org/10.31186/jspi.id.12.3.335-340

Sihombing G, Pratitis W, Dewangga GA (2010). Effect of using earthworm meal (Lumbricus rubellus) on the digestibility of dry matter and organic matter of ration of local male rams. Caraka Tani., 25(1): 80-86. https://doi.org/10.20961/ carakatani.v25i1.15746

Soetrisno E, Jarmuji Andana AN, Amrullah AHK, Harahap AS (2018). The effect of sakurablok plus suplementation on quality of nubian milk goat. J. Sain Peternak. Indonesia, 14(2): 208-214. https://doi.org/10.31186/jspi.id.14.2.208214

SPSS (2017). IBM SPSS Statistics for Windows, Version 25.0. Armonk, NY: IBM Corp.

Tilley JM, Terry RA (1969). A two-stage technique for in vitro digestion of forage crops. J. Br. Grassland Soc., 18(2): 104111. https://doi.org/10.1111/j.1365-2494.1963.tb00335.x

Trotta RJ, Klotz JL, Harmon DL (2018). Effects of source and level of dietary energy supplementation on in vitro digestibility and mehane production from tall fescue-based diets. J. Anim. Feed Sci. Technol., 242: 41-47. https://doi. org/10.1016/j.anifeedsci.2018.05.010

Tylutki TP, Fox DG (1997). Application of the cornell nutrient management planning system: Optimizing herd nutrition. In: Proceedings of cornell nutrition conference for feed manufacturers. New York: Cornell University.

Vasta V, Mele M, Serra A, Scerra M, Luciano G, Lanza M, Priolo A (2009). Metabolic fate of fatty acids involved in ruminal biohydrogenation in sheep fed concentrate or herbage with or without tannins. J. Anim. Sci., 87: 2674-2684. https:// doi.org/10.2527/jas.2008-1761

Wang L, Zhang G, Li Y, Zhang Y (2020). Effects of high forage/ concentrate diet on volatile fatty acid production and the microorganisms involved in VFA production in cow rumen. Animals, 10(2): 223. https://doi.org/10.3390/ani10020223

Wang MZ, Wang HR, Cao HC, Li GX, Zhang J (2008). Effect of limiting amino acids on rumen fermentation and microbial community in vitro. J. Agric. Sci. China, 7: 12. https://doi. org/10.1016/S1671-2927(08)60412-5

Warly L,Suyitman,Evitayani,Fariani A (2015).Suplementationof solid ex- decanter on performance of catlle fed palm fruidt by- product. Pak.J.Nutr., 14(11): 818-821. Open acces. ISSN 1680-5194. https://doi.org/10.3923/pjn.2015.818.821

Warly L, Suyitman, Evitayani, Fariani A (2017). Nutrient digestibility and apparent bioavailability of minerals in beef cattle fed with different levels of concentrate and oil-palm fronds. Pak. J. Nutr., 16(3): 131-135. Open acces. ISSN 1680-5194. https://doi.org/10.3923/pjn.2017.131.135

Zain M, Sutardi T, Suryahadi, Ramli N (2008). Effect of defaunation and supplementation methionine hydroxy analogue and branched chain amino acid in growing sheep diet based on palm press fiber ammoniated. Pak. J. Nutr., 7: 813-816. https://doi.org/10.3923/pjn.2008.813.816

Zhang HL, Chen Y,Xu XL, Yang YX (2013). Effects of branchedchain amino acids on in vitro ruminal fermentation of wheat straw. Asian Aust.J. Anim. Sci., 26(4): 523-528. https://doi. org/10.5713/ajas.2012.12539 